\title{
Analysis and characterization of paleosoil: A preliminary study and possible applications in forensic archaeology
}

\author{
Andrea Nava \\ Section of Forensic Geology, International Forensic Consulting, Manno (Lugano, Switzerland) \\ Email address: \\ anava@telnetwork.it \\ To cite this article: \\ Andrea Nava. Analysis and Characterization of Paleosoil: A Preliminary Study and Possible Applications in Forensic Archaeology. \\ International Journal of Archaeology. Special Issue: Archaeological Sciences. Vol. 3, No. 1-1, 2015, pp. 9-20. \\ doi: $10.11648 /$ j.ija.s.2015030101.12
}

\begin{abstract}
This paper presents the results of analysis conducted on soil samples collected on the Isola delle Statue in Porto Marghera (Venice, Italy). The analyses were aimed at the mineralogical - petrographic characterization and evaluation of the possible presence of layers of a paleo soil (Neolithic age). For the characterization of the sediments have been used different techniques of microscopy, including the plating of the finer fraction of the samples with liquid paraffin and glycole on slide. This partial-destructive technique has allowed us to detect the presence of pollen and biotic remains sometimes undetected in preparations in thin section of the same. The techniques of optical microscopy has been associated with analysis by XRD Method of powder. The combined application of these techniques and analytical methods of optical and diffractometric has a permission to obtain satisfactory results in terms of archaeological characterization. Indeed, the presence of smectite detected by XRD - Method of powder, associated with the presence of detected biotic remains pollen and plant on sample plating, has a permission to highlight the presence of a layer of paleo soil. In this preliminary study, it is seen, therefore, that the method of plating on a glass slide and the study of smectite can be of great help in forensic archaeological investigation for the verification of compatibility and discrimination of traces of soil.
\end{abstract}

Keywords: Forensic Archaeology, Paleosoil, Smectite, XRD, Microscopy

\section{Introduction}

The phase illite - smectite has been recognized to be the product of alteration also natural pyroclastic materials base. Its formation has been attributed to induce leaching by rainwater during the cyclic alternation of wet and dry seasons [4].

It is known that the proportion of interlayer $\mathrm{Al}-\mathrm{OH}$ in smectite increases with the age of the soil [25]. In areas with warm weather, from wet to sub-humid, there are watersheds in which the degradation of metamorphic and igneous rocks can produce sediments rich in kaolinite, illite and Al- smectite. It was also verified that the illite is at times be a mineral of the original parent rock, while the Al-smectite is formed mainly by degradation of phases as the clinocloro $[1,27]$.

The smectites of detrital formations and soils are derived from continental $[2,5,7,9,29,34]$. Numerous mineralogical, micromorphological and geochemical studies have suggested that even the smectite present in the majority of Mesozoic sediments are mainly of continental origin [9, 14].

Furthermore, it is seen that the smectite present in many soils is usually a product of alteration of smectite trioctaedric inherited from the alteration of rocks of basaltic nature [13]. All this basic information can come in handy when working in the forensic archaeological field. Indeed traces of soil adhere to various substrates ( boots, shoes, fabrics, garments and parts of vehicles ) most often differ significantly from the plot of origin for the particle size distribution and the finer fraction appears to be the best representative of the sediment of origin [3, 17]. Determine the origin and / or the compatibility of traces of mud, soil or other geomaterials found on objects can make a significant contribution at all stages of an investigation $[6,15]$. In particular, the stages, clay have been shown to have a good discriminating power and identification of specific formations [25]. Especially it is seen that the most significant differences of the tracks found in it, relative to the ground of origin were found for granulometric classes between 1 and $0.063 \mathrm{~mm}$ [10], and then within the range of particle sizes of the sand. Since the 
70 s the most satisfactory results were obtained for particle size fractions ranging from very fine sand / silt to clay $(<60$ $\mu \mathrm{m})$ [16], which also showed a good reproducibility of the data, while for fractions the class of the sand $(2 \mathrm{~mm}-50 / 60 \mu$ $\mathrm{m})$, the results are less reliable as it is believed there is a significant danger of getting false negatives. It was also estimated that, given the particular circumstances in which the samples are found, the sieve fraction $<150 \quad \mu$ m provides an acceptable compromise between representativeness and validity of the data obtained [23; 24]. Therefore, in addition to the study of particle size distribution for size fractions $<0.05 \mathrm{~mm}$, falling within size classes ranging from very fine sands to clays $[22,31]$ is well associate the mineralogical analysis of the clay component on the same particle size fraction (less than $0.05 \mathrm{~mm}$ ) without extraction of the fraction $<0.002 \mathrm{~mm}$. Studies on the mineralogical compositions obtained by this method showed a number of characteristics related to topographic positions from where they were taken soil samples. The soil samples from the hilly areas in conditions of poor drainage and with a tendency to stagnation, such as those from the plains of the valley and floodplain areas are characterized by the presence of interstratified clay minerals chlorite and vermiculite chloritized. Furthermore, the two environments can be discriminated between them because the former are richer in gibbsite while the latter contain smectite [21].

\section{Sampling}

As part of the work of confinement Isola delle Statue was launched a investigations campaign to verify the presence of remains of paleosoil. Then 26 surveys were performed with continuous core drilling to depths of 10 meters from ground level (Figure.1). Following examination of core drilled were collected 28 samples at various depths. The name of each sample was composed of a first abbreviation refers to the number of the survey (eg. S20) and by a number (eg. 254) indicating the depth of sampling from ground level expressed in centimeters. The Table 1 shows the samples that for convenience have been highlighted using the same color to indicate the macroscopic similarity.

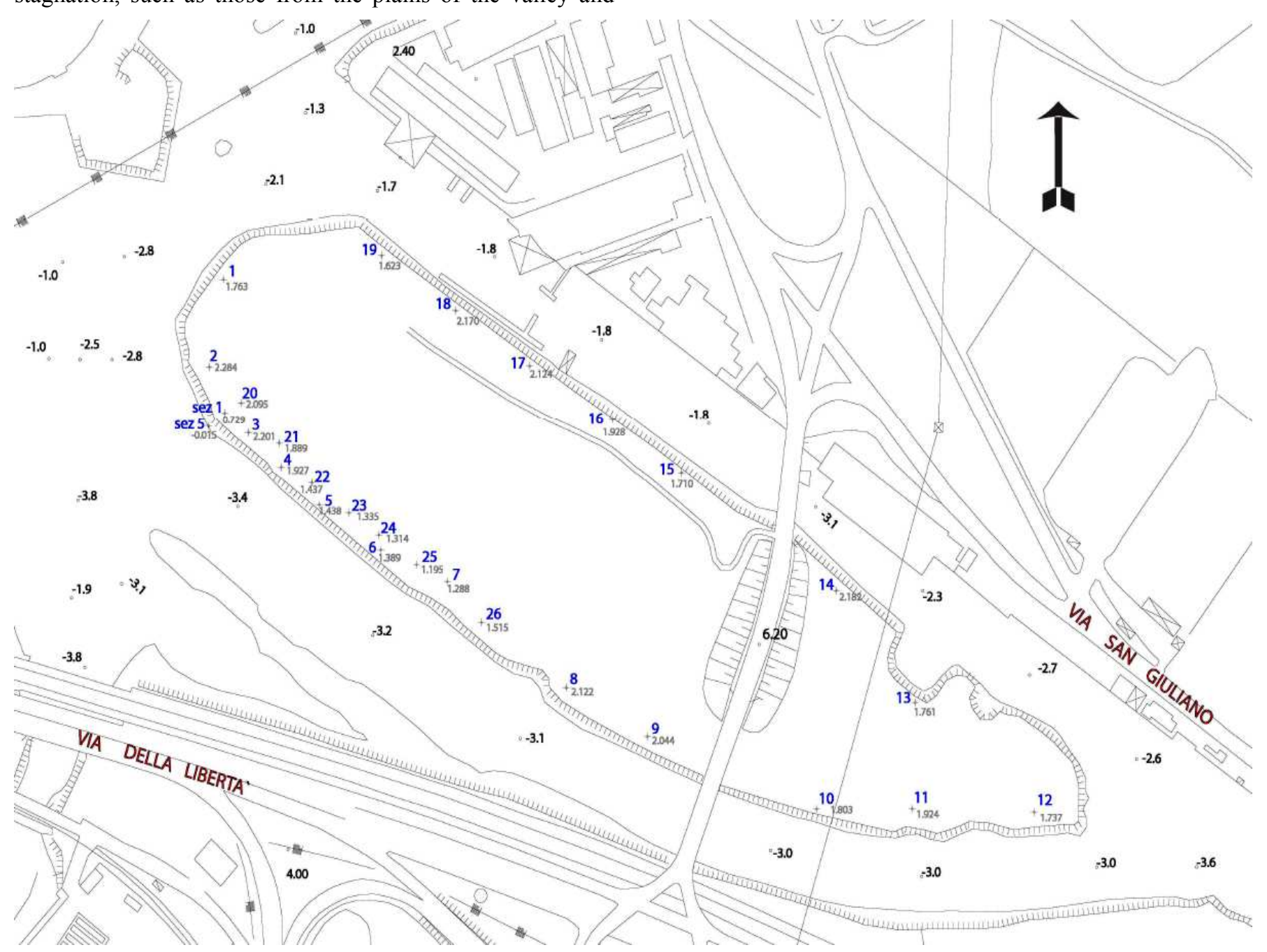

Figure 1. Excerpt from the floor plan with location of the surveys carried out (blue points). 
Table 1. Stratigraphy of analysed survey cores

\begin{tabular}{ll}
\hline Sample & Description \\
\hline Survey 1 & \\
S1-240 & Clayey silt with plant remains and bioclasts (diatoms) \\
S1-260 & \\
S1-285 & Sandy silt with plant remains and bioclasts \\
S1-300 & \\
S1-305 & \\
S1-330 & Slightly silty fine sand gray - beige \\
S1-370 & Slightly silty fine sand with rare bioclasts \\
Survey 7 & \\
S7-248 & Silty clay with abundant vegetal remains and bioclasts \\
S7-274 & Fine sand ocher colored micro stratified \\
S7-290 & \\
S7-330 & Slightly silty fine sand gray - beige \\
Survey 16 & \\
S16-220 & Silty clay with abundant plant remains and bioclasts \\
S16-270 & Sandy silty clay with vegetal remains and concretions \\
S16-295 & Slightly silty fine sand gray - beige \\
S16-340 & \\
Survey 19 & \\
S19-180 & Slightly silty fine sand with abundant bioclasts (beach?) \\
S19-195 & Silty clay with abundant plant remains and bioclasts \\
S19-220 & Silty fine sand with concretions of ocher color \\
S19-275 & Fine sand ocher colored micro stratified \\
S19-330 & Sabbia fine debolmente limosa di colore grigio - beige \\
Survey 20 & \\
S20-223 & Silty clay with vegetal remains and bioclasts (diatoms) \\
S20-244 & Ocher clayey silt with abundant plant remains (paleo soil) \\
S20-254 & Ocher clayey silt with rare plant remains (paleo soil) \\
\hline & Silty fine sand with concretions of ocher color \\
S20 sand ocher colored micro stratified \\
S20 silty fine sand gray - beige \\
\hline
\end{tabular}

\section{Samples Preparation and Examination in Microscopy}

The analyses carried out on samples taken are part of the analytical routine applied for the characterization of soil, and of crystalline materials both natural and artificial.

Of all the 28 samples was made microscopic analysis in reflected light on an aliquot of the sample as-received. After the examination in reflected light, the fraction $<150 \mathrm{~mm}$ in the same aliquot was dissolved in the liquid paraffin and ethylenic glycol, then plated on glass slide and examined in reflected light object with incident light $25^{\circ}-60^{\circ}$ and in the transmitted light optical polarizer stereomicroscope. These analyses were conducted to assess the presence of organic remains type animalian and plant, in order to characterize the sediment in rapidly. With this technique it was possible to operate a first discrimination.

The examination was performed in reflected light stereomicroscope with optical and digital microcam Digivision USB Digital Microscope with Dual Axis Lens with 27X and 100X magnification.

Following were chosen 6 samples, respectively : S20 -223, S20 -244, S20 -254, S20 -264, S20- 272 and S20 -372, which have been prepared on the thin section and examined by optical polarizer stereomicroscope.

The microscopic analysis were performed with the following instrumentation:

stereomicroscope trinocular Horus 72030 oculars WF 10x $118 \mathrm{~mm}$ anaberrant PLAN achromatic objectives $5 \mathrm{x} / 0,1$, $10 x / 0,25,20 x / 0,40,40 x / 0,65$ e $100 x / 1,25$ focusing system with gradual step $0,002 \mathrm{~mm}$ Twin lens optical condenser and iris camera CCD Ever Focus Digital EQ 200/P.

\subsection{Examination of Samples in Microscopy}

Below the results of the analysis on the prepared with the three microscopy techniques described above. For ease of synthesis, the analysis results will be illustrated for groups of samples detected between them very similar.se the abbreviation "Fig. 1", even at the beginning of a sentence.

\subsubsection{Samples S1 -240, S7 -240, S16-220, S19 - 195 and S20 -223 (Sandy Silt and Clay)}

The samples in this group represent the sediments of marine origin overlying the layer of archaeological interest. Generally gray in color more or less dark, silty - clay texture with a skeleton composed of clasts of very fine grain size attributable to the sands. Shells of mollusks, diatoms, foraminifera, and algae frustules generally represent the content of biotic remains.

The depositional environment was characterized by stagnant waters, brackish or marine, however, are characterized by currents, when present, very weak.

Microscopic analysis in transmitted light of plating samples reveals a skeletal fraction consists mainly of quartz, feldspar and calcite / dolomite, in the alternative polimineralic lithic clasts of schistose appearance. There are very abundant foraminifera (Photo 2), the remains of algae and diatoms (Photo 1) in the alternative.

The analysis in thin section highlights a matrix of micro cryptocrystalline (calcite) containing large areas consist of reddish brown bed, ever extinguished at the polarizer, containing abundant chlorite. The skeleton is made up of polycrystalline, microcrystalline granules, and by much altered crystals of calcite, there are also mono-and polycrystalline quartz grains (flint), and rare lithic polycrystalline poly mineral clasts composed of quartz and altered feldspar. Within the sample in thin section have not been found the frustules of diatoms previously highlighted in the samples prepared by plating in glycol.. 


\subsubsection{Samples S20 -244, S20 -254 (Paleo Soil)}

These two samples are composed of sediments of continental origin related to a paleo soil of archaeological interest. The color varies from gray to beige and the texture is clay - loam weakly sandy with a skeleton composed of clasts granulometrically attributable to the fine sands.

The content of plant remains (peat) is abundant in the S20-244, while it is absent in the S20- 254.The continental environment of formation was probably of alluvial, characterized by intermittent currents.

The microscopic analysis in reflected light shows a skeleton consisting of granules of quartz looking predominantly hyaline. Microscopic analysis in transmitted light plating of sample reveals a skeletal fraction consists mainly of quartz, and phyllosilicates (biotite and chlorite ) and feldspars in the alternative. Unlike the previous series of samples, the carbonate phases (calcite and dolomite) are practically absent. The particular was found the presence of tourmaline microcrystals, loose both included in quartz.

Very interesting are the remains of plants showing morphologies leaving assume the presence of pollen of herbaceous, trees or shrubs species (Photo 3). The petrographic analysis of the sample in thin section shows a yellow ocher matrix containing mica ( biotite ) and abundant chlorite. There are flakes shaped pseudo oncoid red brown strongly pleochroic. The skeleton is made up mainly of lithic clasts monomineralic polycrystalline quartz (including chert) and polymineral granules consist of quartz, mica and feldspar Some have a schistose appearance, other traces of pressure dissolution. The mono-crystalline phases present in the skeletal fraction consisted mainly of quartz and altered feldspar; accessories can be found as crystals altered mafic (pyroxene / amphibole ). Is interesting to note that within the sample in thin section have not been found previously highlighted the remains of pollen in the samples prepared by plating in glycol.

\subsubsection{Samples S20 -264, S20 -272, S16- 270 and S19-220 (Sandy Silt - Continental Environment)}

This group of samples belongs to the sediments of continental origin just below the layers of archaeological interest. The levels refer to the paleo soil in the strict sense have been found only in the S20 survey, while this type of sediment has also been found in other surveys. It follows that in all other surveys, the absence of the level of paleosoil overlying leaves hypothesize the onset of more or less intense erosive phenomena. The color of this type of sediments varies from gray to yellow ocher and beige weaving general is predominantly silty slightly sandy, with a skeleton composed of clasts granulometrically attributable to the fine sands.

The levels of paleosoil of these samples are characterized by the presence of more or less marked nodular concretions noticeable to the touch, of micritic calcite and by the presence of dolomite. The content of plant remains is variable while the microfauna is absent.

The continental environment of alluvial formation was characterized by intermittent currents.

The microscopic analysis in reflected light highlights the presence of said nodules that in fracture have a milky white color. Within them are visible hyaline granules while they are delimited by an edge looking sericeous.

The skeleton is made up of quartz grains and granules looking hyaline saccharoid yellowish - ocher in color.

The microscopic analysis in transmitted light of sample plating reveals a skeletal fraction consists primarily of quartz, calcite / dolomite, phyllosilicates ( biotite and chlorite ) while the $\mathrm{k}$ - feldspar and plagioclase are much altered and in ancillary quantity (Photo 4).

The petrographic analysis of the sample in thin section shows a yellow ocher matrix containing calcite, micas ( biotite ) and chlorite in significant quantities and flocs of shape pseudo oncoid and color from yellow ocher to red-brown that are generally strongly pleochroic. There has also rounded nodules of light gray paste cryptocrystalline ( micrite ) containing microcrystals of calcite and quartz.

The skeleton is made up mainly of grains of calcite that is presented in various forms, in clear and regular crystals, or granules monomineralics polycrystalline more or less rounded and in terrigenous clasts of limestone of microcryptocrystalline micrite. Moderate amounts of monomineralics polycrystalline lithic clasts of quartz are present with traces of pressure dissolution and clasts polimineralics looking schist. The mono-crystalline phases present in the skeletal fraction also detected in transmitted light of plating sample consisted mainly of calcite, quartz, plagioclase and rare K-feldspar, usually altered. Are in incidental quantities altered mafic crystals (pyroxene / amphibole)

\subsubsection{Samples S20 -281, S20-297, S19-275, S7-274 and S7-290 (Paleo Soil of Reference)}

The samples discussed below represent the sediments of continental origin constituting the paleo soil of continental environment reference, locally called with the term "Caranto".The color of these samples varies from deep yellow to ocher and beige, texture is generally silty - sandy, with a skeleton composed of clasts granulometrically attributable to the fine sands. The content of plant remains and microfauna is almost absent.

The continental environment of alluvial formation was characterized by intermittent currents.

Visual analysis of the samples are presented ocher color yellow ocher brown in color with levels that follow the apparent micro layers.

The microscopic analysis in reflected light on plating sample shows the presence of a skeleton constituted by quartz grains looking hyaline and granules looking saccaroid in color from yellowish - ocher to brown. The microscopic analysis of the finer fraction of plating sample reveals a skeletal fraction consists mainly of quartz, calcite / dolomite mica abound including biotite and chlorite and rare remains of foraminifera reworked. The petrographic thin section analysis performed on the ssample S20 -297 shows a yellow 
ocher matrix containing calcite, micas (biotite), chlorite. The microlayers that differs in color of the matrix changes from brown to gray beige, and for the particle size of the skeleton. In the microlayer of ocher brown colour are present terrigenous lithic clasts of various nature, of sub - millimeter dimensions ( limestones, sandstones, mudstones, gneiss ); while in the microlayer gray beige prevail much smaller particle sizes of the skeleton, and are characterized by granules mostly monocrystalline quartz and feldspar.

Moderate amounts of lithic clasts of chert and monomineralics polycrystalline quartz with traces of pressure dissolution, and poliy mineralics clasts looking schist. The mono-crystalline phases present in the skeletal fraction consisted mainly of calcite / dolomite, quartz, feldspar and plagioclase.

\subsubsection{Samples $S 1$-330, S7 -330, S16 -295, S16 -340, S19 -330 and S20 -372 (Sandy Sediments at the Base))}

The samples discussed below represent sediments that are located below the paleo soil of continental environment reference, locally called with the term "Caranto". The colour of these samples varies from grey to beige and the general texture is silty - sandy, with a skeleton composed of clasts granulometrically attributable to the fine sands. The content of plant remains and micro-fauna, is almost absent. The training environment was of alluvial type (deltaic?).

The microscopic analysis in reflected light on plating sample shows the presence of a skeleton constituted by quartz grains looking hyaline and granules looking saccaroid yellowish - ocher, in some it was possible to identify crystalline granules with traces of flaking referable the calcite / dolomite. Microscopic analysis in transmitted light plating of sample reveals a skeletal fraction consists mainly of quartz, calcite / dolomite, feldspar and plagioclase, and altered rare remains of foraminifera reworked. The petrographic thin section analysis performed on the sample S20 -372 shows a matrix containing predominantly beige quartz, calcite and chlorite. Overall, the skeleton is made up mainly of grains of calcite altered, rounded lithic clasts of limestone and siliciclastic clasts of micrite. Moderate amounts of lithic clasts mono-mineralics polycrystalline quartz with traces of of pressure dissolution, and silica, as well as polymineralics clasts looking schist. The mono-crystalline phases present in the skeletal fraction consisted mainly of calcite / dolomite, quartz, feldspar and plagioclase.

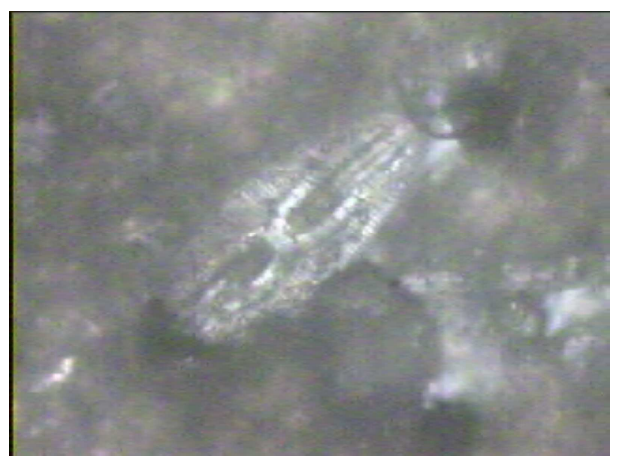

Photo 1. S1-240: Detail of diatom $[40 x-P G]$

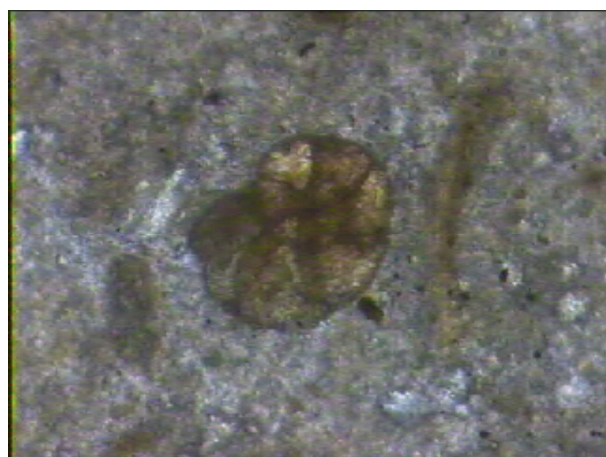

Photo 2. S7-248: Foraminifera [10x - PP]

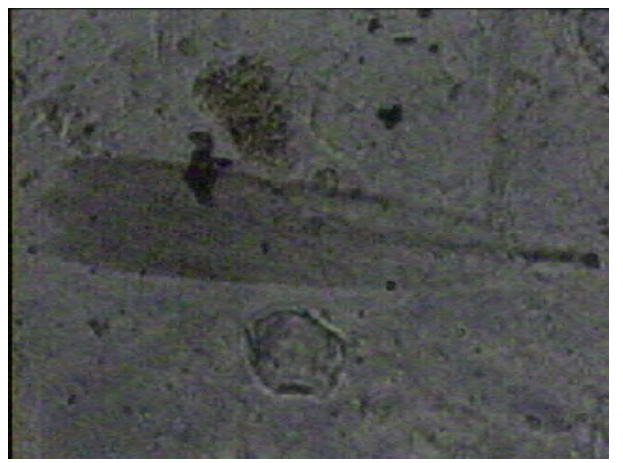

Photo 3. S20-244: Rest of biotic plant (pollen?) [40x-pol - PP]

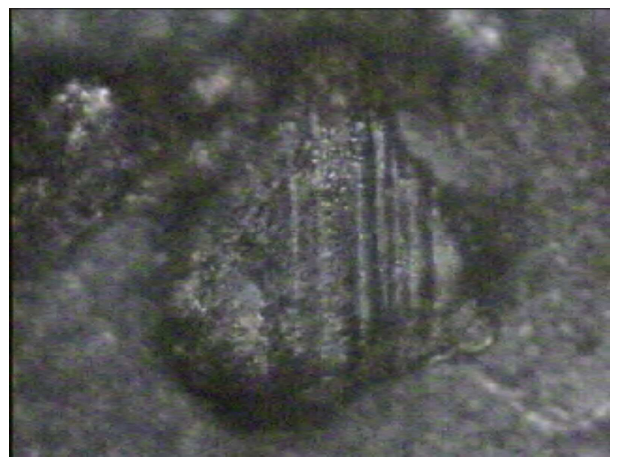

Photo 4. S19-220: Grain of strongly altered feldspar [20x - PP]

The micro photographes were taken on samples prepared by plating in glycol (PG) or paraffin (PP)

\section{XRD Analysis}

This analytical method allows the identification and semi-quantitative determination (mass $\%$ ) of crystalline phases that constitute the samples .

Of the 23 samples tested with microscopy techniques previously described, only 2 were found to be representative of a paleo soil: S20/244 and S20/254. The sample S20/264 was found to be representative of an intermediate situation compositionally, closer to "Caranto". To dispel any doubts of compatibility between the 3 samples, has been done on them an X-ray diffraction analysis.

The analyses on the samples were performed with the following instrumental characteristics:

- Philips diffractometer model PW1800/10 
- data processing software X' Pert High Score - v. 1.0b (Philips)

- radiation $\mathrm{CuK} \quad(\mathrm{K} \quad 1=1.54060 \AA \mathrm{K} \quad 2=1.54439 \AA)$

- monochromator : graphite

- automatic divergent slide

- power generator: $45 \mathrm{Kv}, 35 \mathrm{~mA}$

- scanning range: 2 - $65 \quad 2$

- scan speed : $0.02 \quad 2 / \mathrm{sec}$

Because of differences arising from the microscopic analysis of the samples S20-244, S20-254 compared to the sample S20-264, three respective rates of the samples were subjected diffraction analysis on the sample as it is.

On these samples were also carried out the standard pre-treatment for the diagnosis of clay minerals: treatment with ethylene glycol and the heat treatment at $550^{\circ} \mathrm{C}$ specifics for the detection of swelling minerals.

- sample as it is (Nat);

- after saturation with ethylene glycol at $60{ }^{\circ} \mathrm{C} / 4$ hours (Gly);

- after heating to $550^{\circ} \mathrm{C} / 2$ hours $\left(550^{\circ} \mathrm{C}\right)$.

The diffractograms $\mathrm{X}$, shown below, show a series of reflections (peaks) characterized by an angular value, expressed in degrees 2 , or the corresponding spacing (d) expressed in $\AA$, taken from Bragg's law ( $2 \mathrm{~d}$ sen $=\mathrm{n}$ ); each reflection is also characterized by an intensity.

The data obtained from X-diffraction analysis of the sample were compared with those reported in the literature (JCPDS:
Joint Committee on Powder Diffraction Standards) and with the data (diffraction X) of standards developed at the laboratory of the Dipartimento di Scienze della Terra, University of Pavia. In particular, the diffraction analysis was conducted between 2 $=2$ and $2=60$ to determine the total composition (Table 3) and in slow scan between $2=2$ and $2=40$ to highlight the composition of the clay fraction (Table 4 ).

Table 2. Mineralogical composition of the samples (wt\%)

\begin{tabular}{llll}
\hline Mineral & S20/244 & S20/254 & S20/264 \\
\hline Dolomite (dol) & 0 & 0 & 23 \\
Calcite (CC) & 0 & 0 & 17 \\
Quartz (Qz) & 33 & 26 & 17 \\
K-Feldspar (K-Feld) & 6 & 4 & 0 \\
Plagioclase (Plg) & 8 & 13 & 6 \\
Mica & 25 & 27 & 21 \\
Cholorite (Clo) & 23 & 23 & 16 \\
Smectite (Sme) & 5 & 7 & 0 \\
\hline
\end{tabular}

Two of the three samples: S20/244 and S20/254 have a very similar composition, in both was also detected, albeit and in a small percentage, the presence of a mineral with swelling characteristics attributable to the group of smectite.

The third sample (S20/264) instead has a composition different from the first two, in particular, was found a fair amount of two carbonate minerals: calcite and dolomite, there is also no mineral of the smectite group. The Table 2 shows the results of the mineralogical compositions of the samples expressed in percentage by weight:

Table 3. Paths diffraction $R x(2 \theta=2-60)$ of the samples

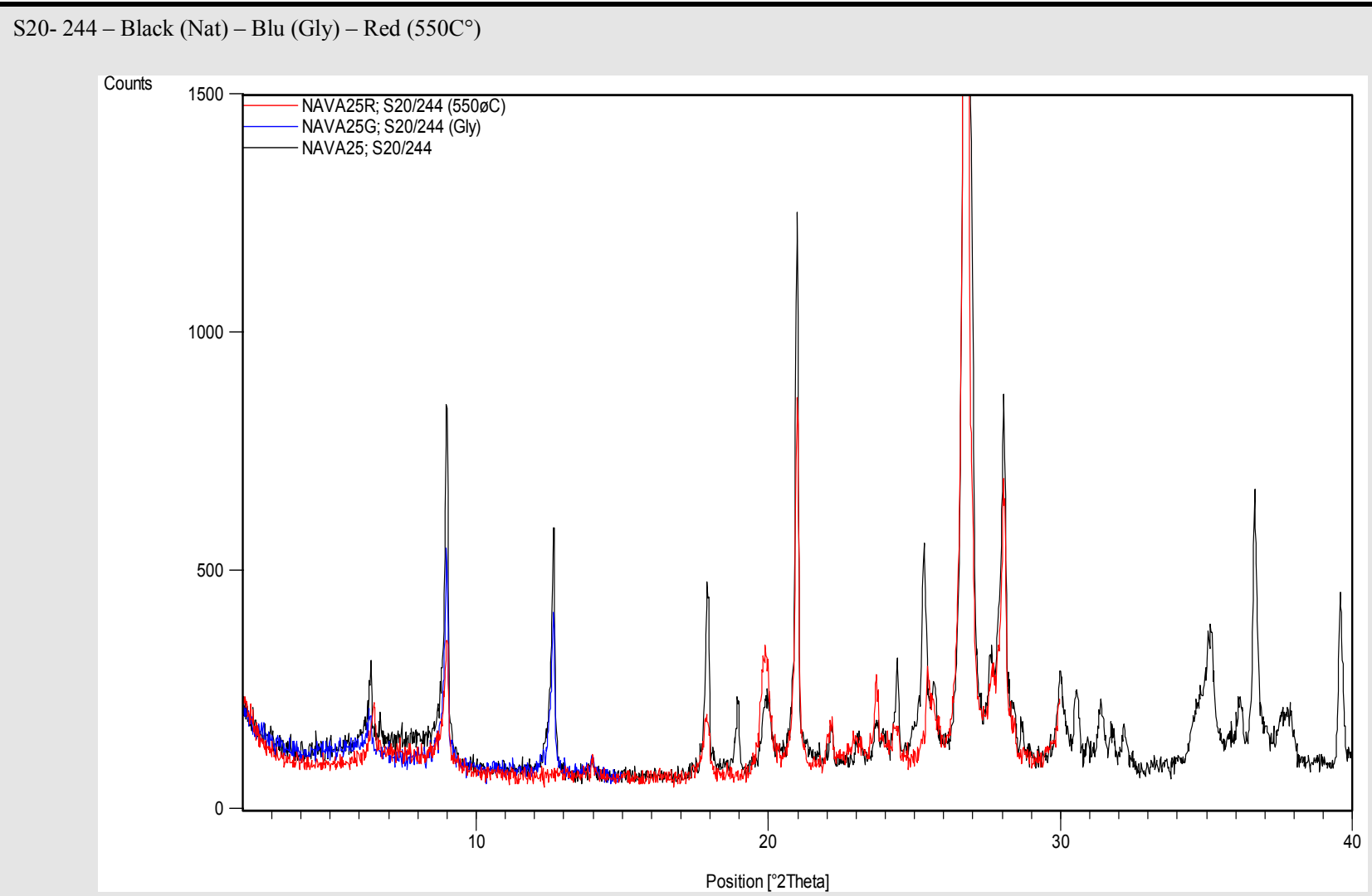




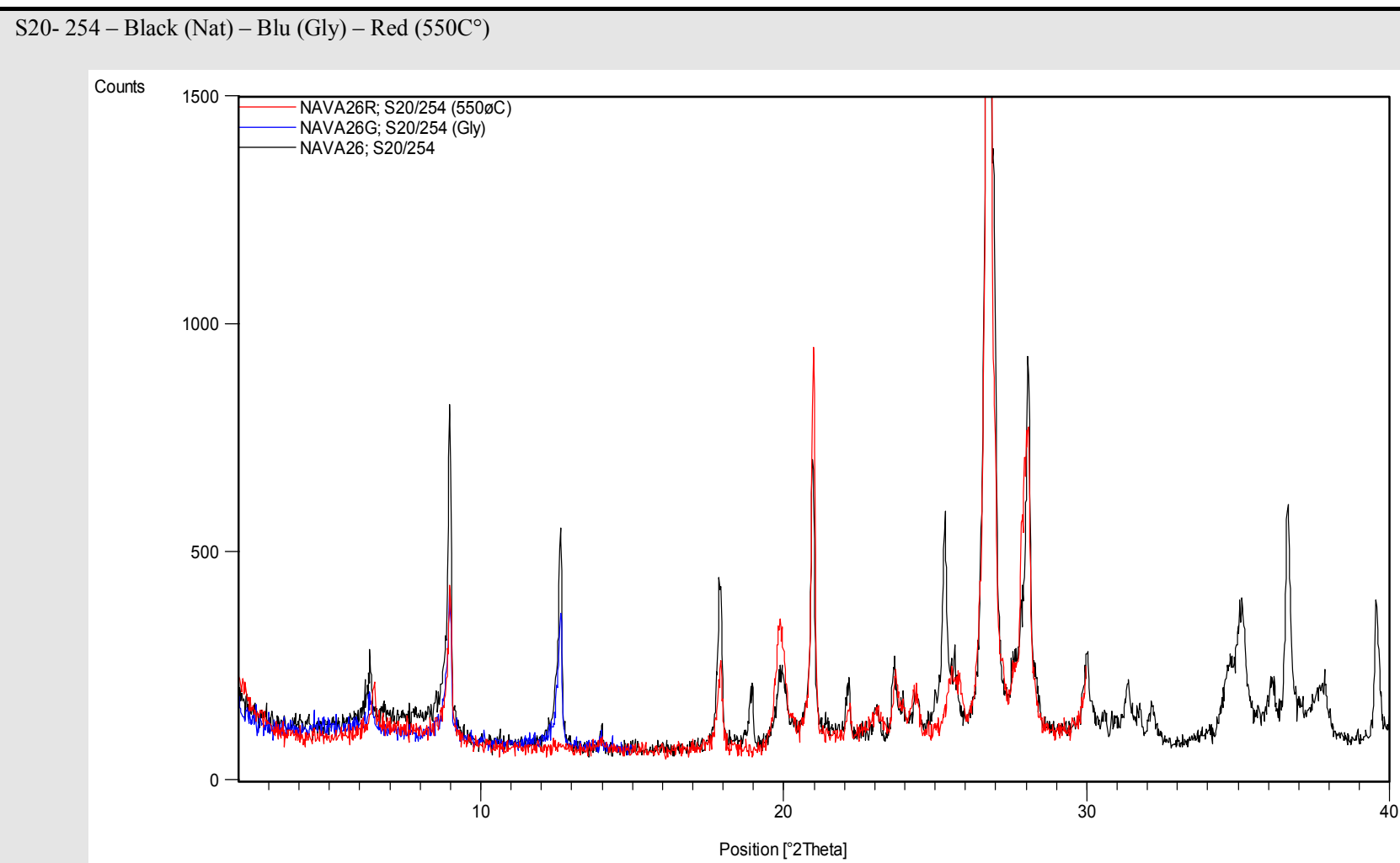

S20- 264 - Black (Nat) - Blu (Gly) - Red $\left(550 \mathrm{C}^{\circ}\right)$

Counts

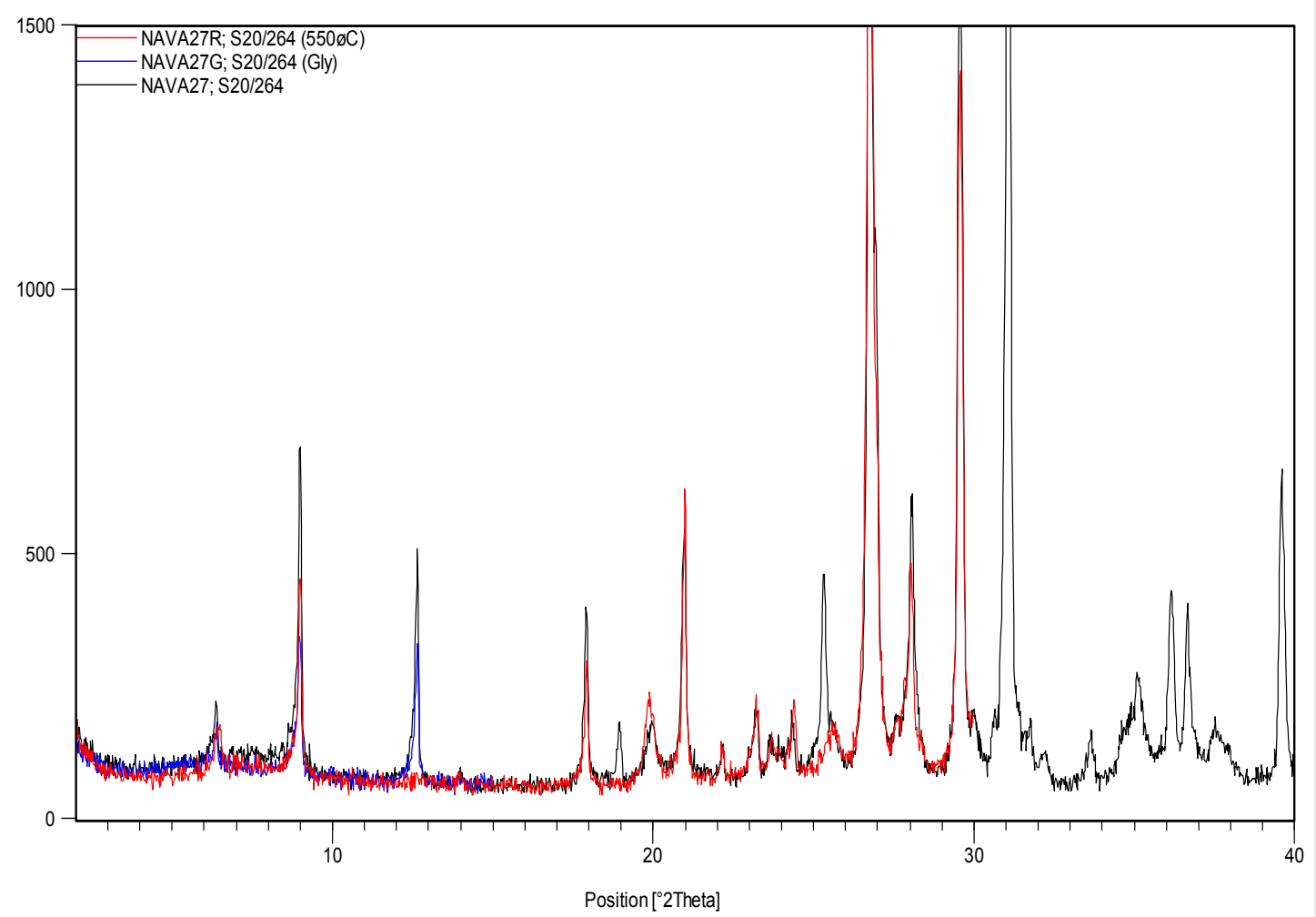


16 Andrea Nava: Analysis and Characterization of Paleosoil: A Preliminary Study and Possible Applications in Forensic Archaeology

Table 4. Paths diffraction Rx in slow scan $(2 \theta=2-40)$ of the sample.

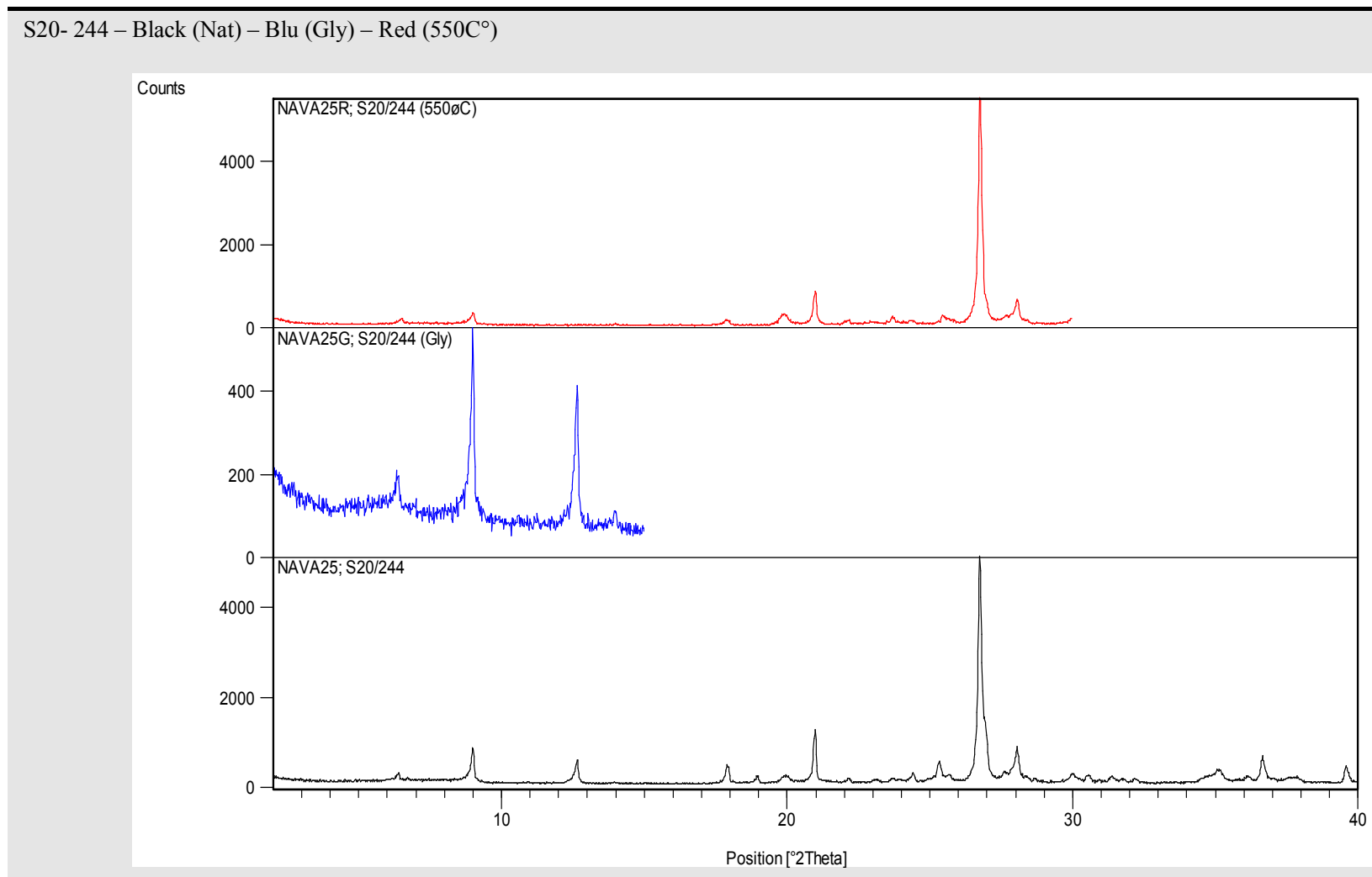

S20- 254 - Black (Nat) - Blu (Gly) - Red $\left(550 \mathrm{C}^{\circ}\right)$

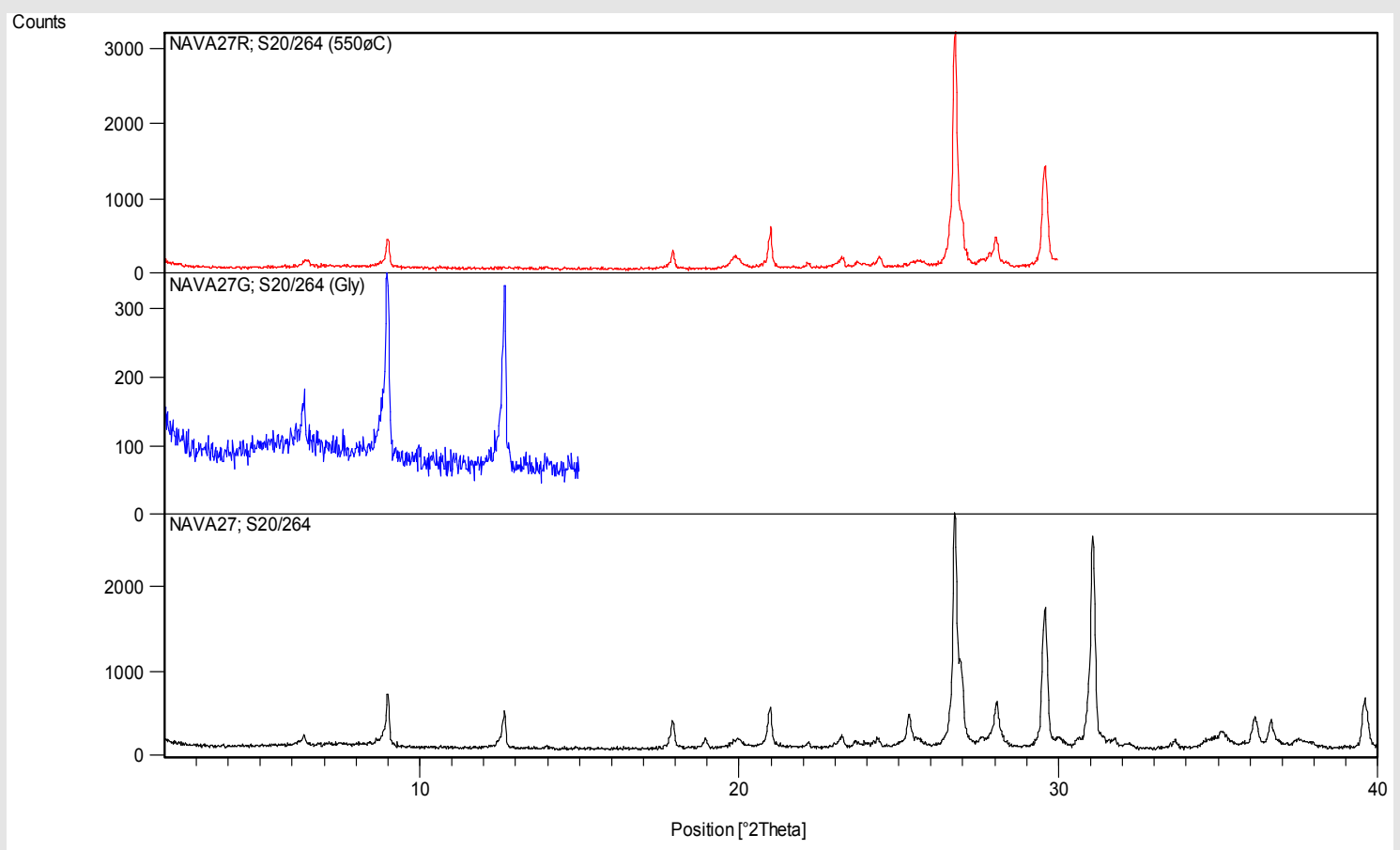




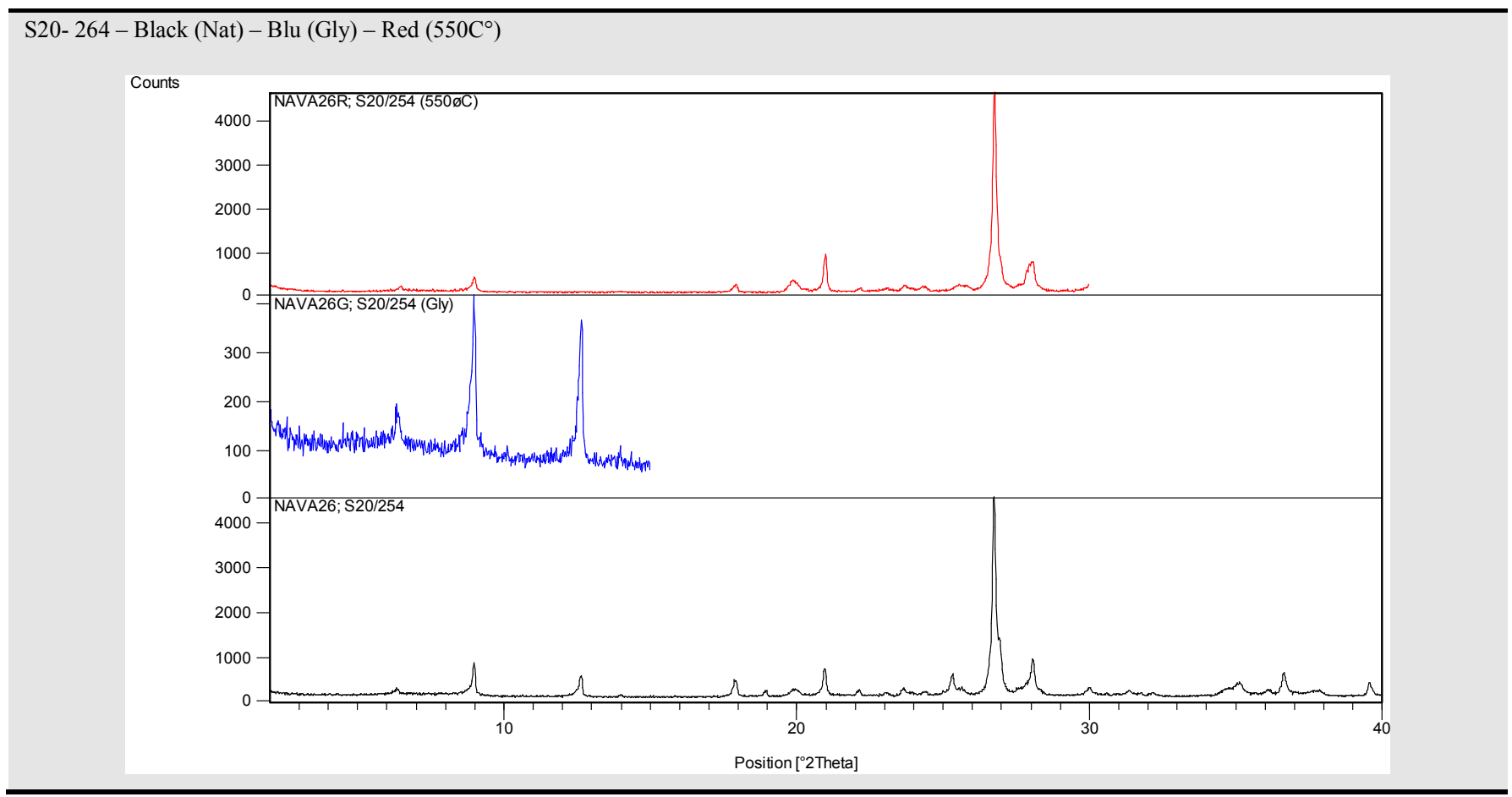

\section{Results and Discussion}

The analyses carried out on samples in plating glycol ethylene and paraffin have revealed the presence of pollen and other organic plants and animals as foraminifera, diatoms and remains of algae that have gone somehow lost during preparation steps in thin section. With this technique, which instead preserves the sample in its entirety, it was possible to discriminate from the beginning although in a summary and expeditious manner, samples from the remaining paleosoil. Furthermore, this technique has allowed performing subsequent targeted analysis on a number of samples extremely reduced with consequent reduction of time and costs.

The presence of smectite highlighted by $\mathrm{Rx}$ diffraction analysis, associated to the pollen detected under the microscope, has allowed assigning the samples and S20/244 S20/254 to a layer of paleo soil. In particular, the presence of smectite associated with chlorite has allowed us to determine which likely depositional environment, a flood plain, in agreement with the geological history of the area (paleo deltaic of the river Po).

Through the study of the compositional relationships conducted with ternary diagrams (Diag.), it is shown that the presence of carbonate phases (calcite and dolomite) in the sample S20/264 compared to the first two (S20/244 and S20/254) allowed to discriminate clearly, in terms of the total composition, the samples of paleo soil by the underlying sediments (Diag.1). In fact, it is clearly seen that there is a clear separation between the two compositional samples of paleo soil S20/244 and S20/254, which are almost identical by total composition, compared to the sample S20/264. However it is noted that between the roof and the bed of the layer of paleo soil you notice a progressive increase of the contents of smectite and a corresponding decrease in the content of K-feldspar (Diag.2). This finding may indicate the presence of chemical weathering processes common in a temperate continental, during the formation of the sediment investigated.

In a possible application in forensic archaeology of this type of analytical battery it seems that a key role in terms of discriminative power is assumed by the ratio between the mineral phases that are contained in smaller amounts than the major constituents of the samples during the excavations.

If we should be faced with the need to decide on the compatibility between the samples S20/244 and S20/254 you would pass by a superposition at the level of the overall composition shown in Diag.1 to an incompatibility highlighted by all other diagrams.

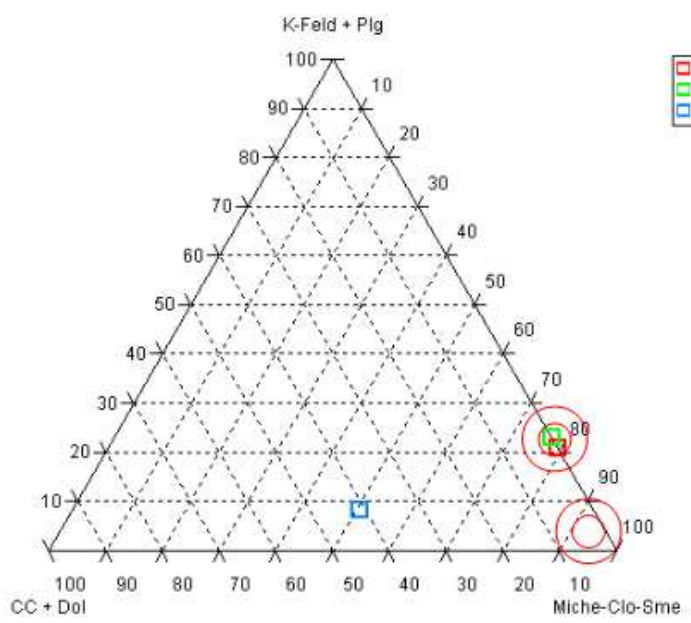

Diagram 1. Evaluation of the relationship between compositional phases: feldspar K-feldspar + plagioclase $(\mathrm{K}$-Feld + Plg); total fillosililcates Smectite + Chlorite + Miche (Miche + Clo + Sme) and carbonates Calcite + Dolomite $(C C+$ Dol $)$. 
In particular, we see in this case that the greatest discriminating power appears to be given by the ratio between k-feldspar and smectite (Diag.2).

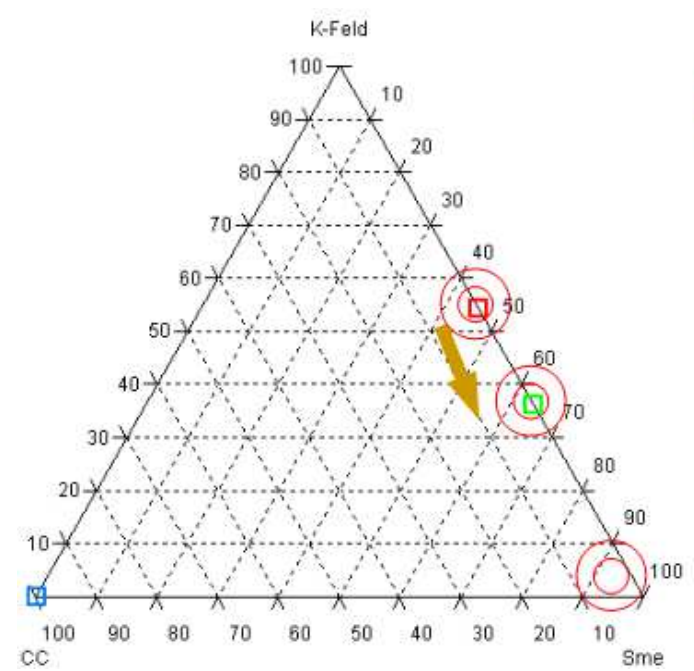

Diagram 2. Evaluation of the relationship between compositional K-feldspar (K-Feld), Smectite (Sme) and Calcite (CC).

This discriminating capacity is drastically reduced when we consider the relationship between k-feldspar + plagioclase and smectite + chlorite, or rather the ratio in terms of the total composition between feldspathic phases and clay phases (Diag.7). Olso the replacing the chlorite to smectite reduce the discriminating ability (Diag.6).

Excluding the carbonate phases is seen as the only smectite content in relation to the relative amount of feldspar phases and quartz, is just barely able to discriminate the three samples (Diag.3), as well as from the comparison between the content of only feldspathic phases with the relative content in quartz (Diag.5). A much more effective discrimination is obtained by dividing the content of the smectite individual phases, K-feldspar and plagioclase (Diag.4)
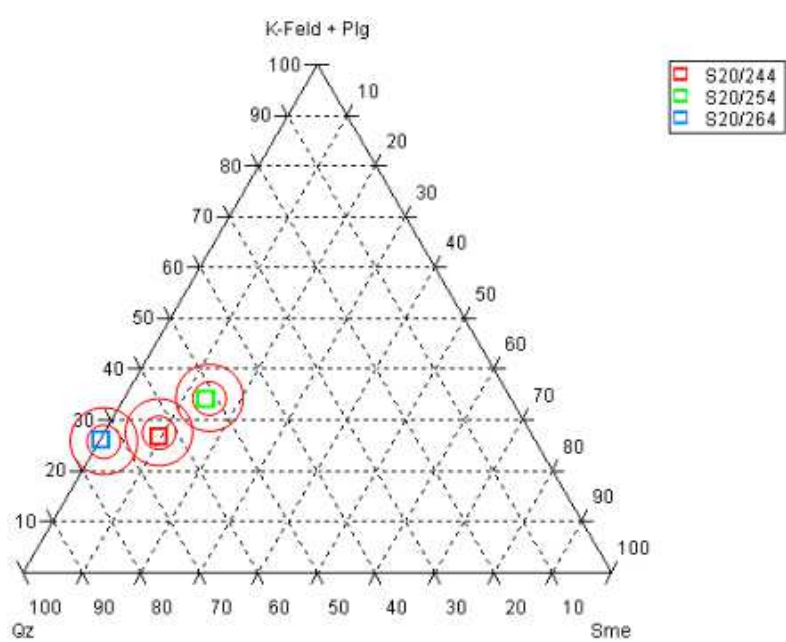

Diagram 3. Evaluation of the relationship between compositional phases $K$-feldspar + plagioclase feldspar $(K$-Feld + Plg), quartz $(Q z)$ and smectite (Sme).

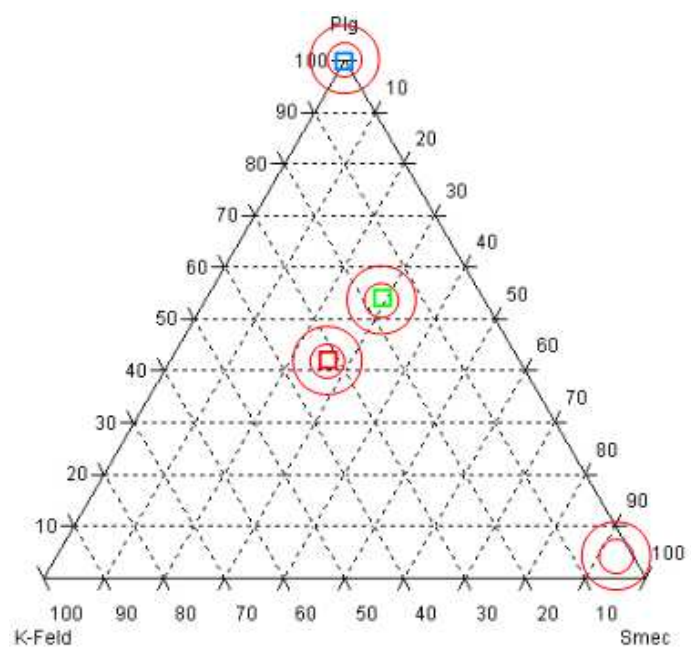

Diagram 4. Evaluation of the relationship between compositional phases feldspar K-feldspar (K-Feld) Plagioclase (Plg), and Smectite (Smec).

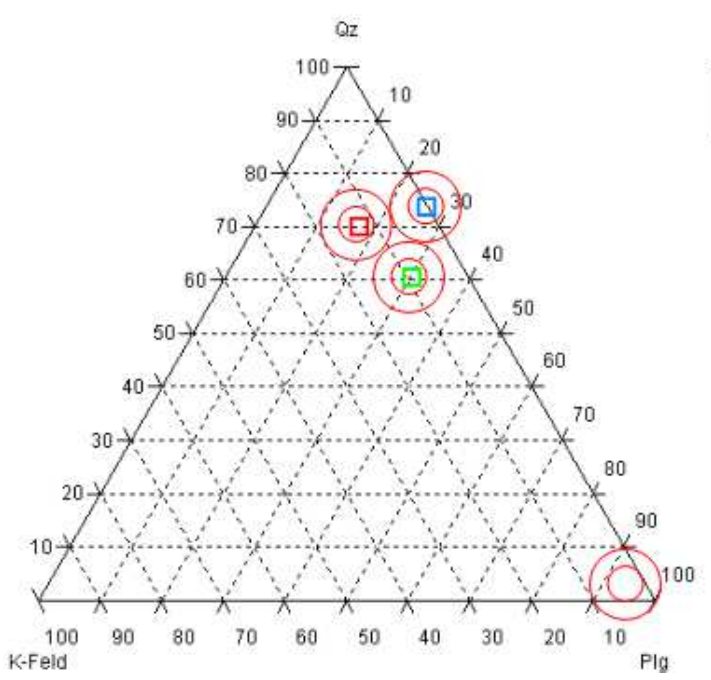

Diagram 5. Evaluation of the relationship between compositional phases feldspar K-feldspar (K-Feld) Plagioclase (Plg), and Quartz (Qz).

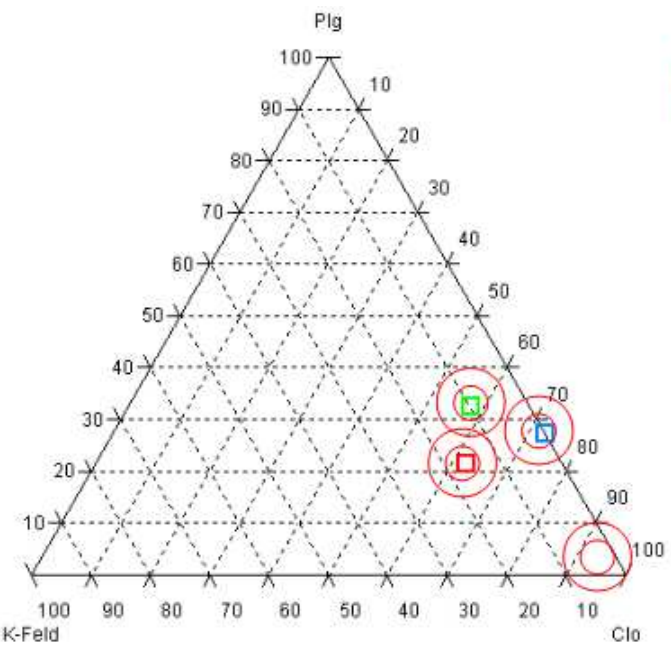

Diagram 6. Evaluation of the relationship between compositional phases of feldspar K-feldspar (K-Feld) Plagioclase (Plg), and Chlorite (Clo). 


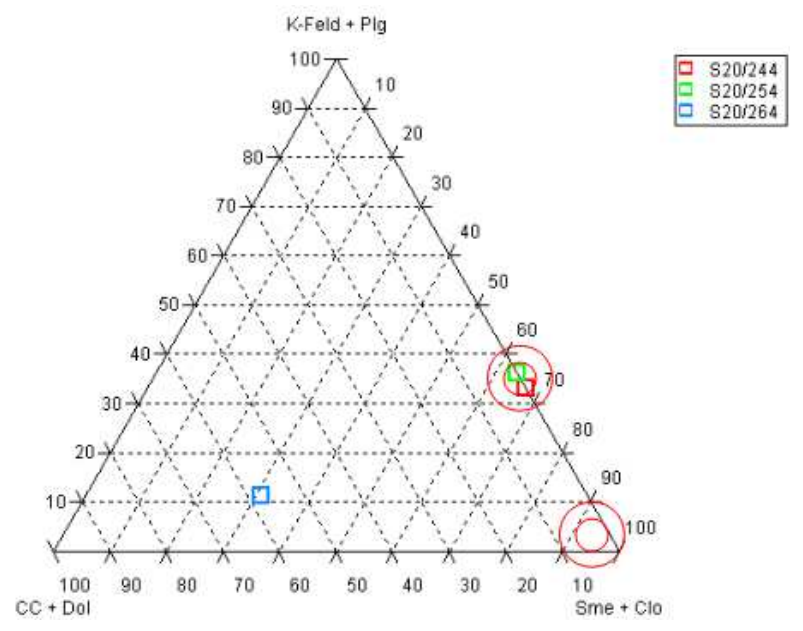

Diagram 7. Evaluation of the relationship between compositional phases: feldspar K-feldspar + plagioclase $(\mathrm{K}$-Feld + Plg); total clay minerals Smectite + Chlorite $($ Sme + Clo) and carbonates Calcite + Dolomite $(C C+$ Dol).

It follows that by using the comparison of analytical data in terms of the total composition of the two samples (S20244 and S20 -254) yields a result of compatibility. However, when you try to evaluate the relationships between the detected phases, significant differences are obtained that lead to the definition of incompatibility between the two samples. In this case, the relationship between the content of K-feldspar / smectite has the highest discriminating power.

\section{Conclusions}

The absence of remains of foraminifera and the content of smectite indicate that the samples S20- 244 and S20 -254 are representative of a paleosoil for that extension would be localized in the vicinity of the survey S20. It is not excluded, however, that such paleosoil may have stored in other points, in correspondence of high stratigraphic, not investigated in this campaign.

In other areas investigated are present evidence of the basal part of this paleo soil represented by the samples of the group S20- 264. The presence of limestone nodular concretions could be the result of the processes of leaching by rain and surface waters, leaching and subsequent recrystallization of the limestone fraction contained originally in the layers above it (the paleosoil of archaeological interest). The presence of smectite in the paleo soil and above that of calcite nodules in this part below may be a testimony of the processes of chemical weathering common in temperate continental environment. Below the paleosoil reference (called "Caranto") the composition of the sands may indicate a type of deltaic depositional environment .

Small aliquot of samples dissolved in the liquid paraffin and ethylenic glycol, then plated on glass slide, examined with optical polarizer stereomicroscope have allowed us to detect organic remains.

This partial-destructive technique has allowed us to detect the presence of pollen and diatoms sometimes lost during preparation of samples in thin section. In fact, during a forensic archaeological excavation, microscopic examination of the sample prepared on thin section could raises some doubts about the representativeness of the analyte in the strict sense. Inasmuch the preparation phase already starts from a fraction of a sample of about $100 \mathrm{~mm}$ thickness, which is then brought to abrasion untill $30 \mathrm{~mm}$ by destruction and loss of $70 \mathrm{~mm}$ thickness. Consequently, $70 \%$ of the sample initially fixed on slide is irretrievably lost.

The smectite proved to be an excellent indicator of paleo environment, particularly relevant discriminating stratigraphy in forensic archaeology.

The greater discriminatory power in this case, was assumed by K- feldspar/smectite ratio. In addition, the XRD Powder analysis of the samples has highlighted the possibility of discriminating samples satisfactorily.

It also stressed the strong compositional variability observed in only $10 \mathrm{~cm}$ deep and the danger of getting de false negative or false positive results caused by errors in sampling phase or evidence collection and if the data are not carefully treated and evaluated.

This gives rise to the need and the subsequent proposal to define standard of comparison of methodological and analytical universally accepted that they could be applied to forensic archaeology.

\section{References}

[1] Bailey, S.W., (1980). Structures of layer silicates. In:G.W. Brindley and G. Brown (Editors), Crystal Structure of Clay Minerals and Their X-ray Identification. Miner. SOC. London, Mono. 5:pp.1-124.

[2] Bauluz Lázaro B., (2007) Illitization processes: Series of dioctahedral clays and mechanisms of formation,-http://www.ehu.es/sem/seminario_pdf/SEMINARI OS_SEM_3_31.pdf

[3] Bergslien E. (2012) An Introduction to Forensic Geoscience, Ed. Wiley, pp.471

[4] Berkgaut, V., Singer, A., and Stahr, K. (1994). Palagonite reconsidered: Paracrystalline illite- smectites from regoliths on basic pyroclastics. Clays and Clay Minerals, 42, 582-592.

[5] Biscaye P.E. (1965). Mineralogy and sedimentation of recent deep-sea clay in the Atlantic Ocean and adjacent seas and oceans. Geological Society of America Bulletin, 76, 803-832.

[6] Bull P. A., Parker A., Morgan R.M. (2006), The forensic analysis of soils and sediment taken from the cast of a footprint, Forensic Science International, Volume 162, Issues 1-3, 16 October 2006, pp. 6-12

[7] Burras L., Smeck N.E., Bigham J. M. (1996) Origin and Properties of Smectite in Loess - derived Soils of Western Ohio SSSAJ Vol. 60 No. 6,1961-1968

[8] Castelli M., Marello S., Marinoni L., Setti M. (2006). Caratterizzazione del materiale marnoso appartenente a zone di deformazione tettonica nelle langhe, Incontro Annuale dei Ricercatori di Geotecnica 2006 - IARG 2006

[9] Chamley H. (1989). Clay Sedimentology. Ed.Springer, pp.623. 
[10] Chazottes V., Brocard C., Peyrot B. (2004) Particle size analysis of soils under simulated scene of crime conditions: the interest of multivariate analyses.Forensic Science International, Volume 140, Issues 2-3, 10 March 2004, Pages 159-166.

[11] Chilingarian G.V., Wolf K.H. (1994). Diagenesis, IV Ed. Elsevier, pp. 529.

[12] Clemente R.R., Tardy Y. (1986). Geochemistry and Mineral Formation in the Earth Surface: Proceedings of the International Meeting "Geochemistry of the Earth Surface and Processes of Mineral Formation", Granada (Spain), 16-22 March, 1986 - CSIC Press, pp.893.

[13] Curtin D. et Smillie G.W. (1981) Composition and origin of smectite in soils derived from basalt in northern Ireland. Clays and Clay Minerals, Vol. 29, No. 4, 277-284.

[14] Deconinck J. F. et Chamley H. (1995) Diversity of smectite origins in late cretaceous sediments: example of chalks from northern France Clay Minerals 30, 365-379.

[15] Di Maggio R.M. and Nuccetelli L. (2006) Forensic soil analyses applied to the Laura M. homicide case, Philadelphia Annual Meeting (22-25 October 2006) Paper No. 168-4.

[16] Dudley R.J., (1976) The Particle Size Analysis of Soils and its Use in Forensic Science - The Determination of Particle Size Distributions Within the Silt and Sand Fractions. Journal of the Forensic Science Society, Volume 16, Issue 3, July 1976, P.p. 219-229.

[17] Ehrmann W. (1998) Implications of Late Eocene to Early Miocene clay mineral assemblages in McMurdo Sound (Ross Sea, Antarctica) on paleoclimate and ice dynamics. Paleogeography, Paleoclimatology, Paleoecology, 139, 213-231.

[18] Halterman D.J. Jr, Gunter M.E.et Williams T.J., (2006) Feldspar forensics: a case study in northern Idaho, Philadelphia Annual Meeting (22-25 October 2006) Geological Society of America Abstracts with Programs, Vol. 38, No. 7, pp. 367

[19] Kohn M.J. (2007). Paleoaltimetry: geochemical and thermodynamic approaches, Geochemical Society, United States. Dept. of Energy, Geological Society of America. Meeting, Mineralogical Society of America, 2007 - pp. 278.

[20] Laszlo P. (2012). Preparative Chemistry Using Supported Reagents Ed. Elsevier, pp. 560.

[21] Marumo Y., Nagatsuka, S. and Oba, Y. (1988) Rapid Clay Mineralogical Analysis for Forensic Science Investigation Clay Mineralogy Over The Short Distances. Journal of Forensic Sciences 33(6):1360-1367.

[22] Pye K., Blott S.J. (2004) Particle size analysis of sediments, soils and related particulate materials for forensic purposes using laser granulometry, Forensic Science International, Volume 144, Issue 1, 11 August 2004, p.p. 19-27.
[23] Pye K., Blott S.J., Croft D.J., Carter J.F. (2006) Forensic comparison of soil samples: Assessment of small-scale spatial variability in elemental composition, carbon and nitrogen isotope ratios, colour, and particle size distribution. Forensic Science International Volume 163, Issues 1-2, 10 November 2006, pp. 59-80.

[24] Pye K., et Croft D. (2007) Forensic analysis of soil and sediment traces by scanning electron microscopy and energy-dispersive X-ray analysis: An experimental investigation. Forensic Science International Volume 165, Issue 1, 5 January 2007, p.p. 52-63.

[25] RawlinsB.G., Kemp S.J., Hodgkinson E.H., Riding J.B., Vane C.H., Poulton C., Freeborough K. (2006) Potential and Pitfalls in Establishing the Provenance of Earth-Related Samples in Forensic Investigations, J Forensic Sci, July 2006, Vol. 51, No. 4.

[26] Ryana P.C. et Huertas F.J. (2009). The temporal evolution of pedogenic $\mathrm{Fe}-$-smectite to $\mathrm{Fe}-$ kaolin via interstratified kaolin-smectite in a moist tropical soil chronosequence. Geoderma 151, pp.1-15.

[27] Ruffel A. et Wiltshire P. (2004) Conjunctive use of quantitative and qualitative X-ray diffraction analysis of soils and rocks for forensic analysis, Forensic Science International 145 13-23.

[28] Sàez A., Inglès M., Cabrera L., De Las Heras A. (2003). Tectonic-palaeoenvironmental forcing of clay-mineral assemblages in nonmarine settings: the Oligocene-Miocene As Pontes Basin (Spain), Sedimentary Geology 159, pp.305 - 324.

[29] Singer A. (1984). The paleoclimatic interpretation of clay minerals in sediments: A review. Earth-Science Reviews, 21, 251-293.

[30] Srodon J. (2006) Identification and quantitative analysis of clay minerals, Handbook of Clay Science, Ed. F. Bergaya, B.K.G., Developments in Clay Science, Vol. 1.

[31] Sugita R., Marumo Y. (2001) Screening of soil evidence by a combination of simple techniques: validity of particle size distribution. Forensic Science International, Volume 122, Issues 2-3, 1 November 2001, pp. 155-158.

[32] Velde B.(1995). Origin and Mineralogy of Clays. Springer, pp.334.

[33] Weaver C.E. (1989). Clays, Muds, and Shales, Developments in Sedimentology 44, pp.819.

[34] James N.P. and Choquette P.E. (1984) Diagenesis 9 Limestones - The meteoric diagenetic environment. Geoscience Canada 11, 161-194.

[35] Zevenbergen, C., Van Reeuwijk, L., Bradley, J., Bloemen, P., and Comans, R. (1996) Mechanism and conditions of clay formation during natural weathering of MSWI bottom ash. Clays and Clay Minerals, 44, 546-552. 